\title{
KAJIAN PROFILISASI ASET INFORMASI MENGGUNAKAN INFORMATION ASSET PROFILING DAN KUANTIFIKASI NILAI EKONOMISNYA BERDASARKAN ANALISIS RISIKO PADA INDUSTRI RUMAH SAKIT
}

\author{
Mohamad Tri Wicaksono dan Benny Ranti \\ Fakultas Ilmu Komputer, Universitas Indonesia, Kampus UI Depok, Jawa Barat, 16424, Indonesia \\ E-mail: triwicaksono@gmail.com
}

\begin{abstract}
Abstrak
Salah satu isu utama dalam industri kesehatan adalah kurangnya manajemen yang tepat dalam aset informasi. Hilangnya aset informasi dapat diklasifikasikan sebagai bencana yang dapat mengakibatkan kerugian finansial. Seringkali, ini kerugian keuangan sulit untuk menghitung karena nilai ekonomi dari aset informasi tidak diukur. Penelitian ini akan membahas informasi manajemen aset di industri kesehatan menggunakan Steven Informatian Profil Aset (IAP), khususnya pada proses bisnis inti. Kuantifikasi nilai ekonomi aset informasi dilakukan melalui analisis risiko menggunakan diagram tulang ikan. Ini adalah hasil pemetaan risiko dalam kategori Ranti yang Generik / TI Nilai Bisnis, dikombinasikan dengan empat $\mathrm{Su}$ model dampak bisnis (keuangan, operasional, pelanggan, dan karyawan). Hal ini bertujuan untuk membantu menentukan metrik yang menunjukkan kuantifikasi kerugian finansial yang mungkin timbul dari kehilangan informasi aset. Hasil penelitian ini menunjukkan bahwa IAP dapat digunakan sebagai metode manajemen informasi aset, serta praktek terbaik dalam penerapan awal manajemen risiko. Penelitian ini juga menemukan bahwa nilai aset informasi tidak selalu sesuai dengan nilai positif ekonominya karena tergantung pada tingkat pemulihan data di masing-masing aset.
\end{abstract}

Kata Kunci: aset informasi, information asset profiling (IAP), kuantifikasi aset informasi,manajemen risiko

\begin{abstract}
One primary issue in healthcare industry is the lack of proper management in its information asset. The loss of information asset can be classified as a disaster that might lead to financial loss. Often, this financial loss is hard to calculate since the economic value of the information asset is not quantified. This study will address information asset management in healthcare industry using Steven's Informatian Asset Profiling (IAP), specifically on its core business process. Quantification of the economic value of information asset is performed through risk analysis using fishbone diagram. It is the mapping result of risks categories in Ranti's Generic IS/IT Business Value, combined with Su's four models of business impact (financial, operational, customer, and employee). It aims to help determining quantification metrics which shows financial loss that might result from information asset loss. The result of this study shows that IAP can be used as a method of information asset management, as well as the best practice in the early application of risk management. The study also finds that information asset value does not always correspond positively with its economic value as it depends on the level of data recovery in each asset.
\end{abstract}

Keywords: information asset, information asset profiling (IAP), information asset quantification,risk management

\section{Pendahuluan}

Kemudahan yang diberikan oleh Sistem Informasi dan Teknologi Informasi (SI/TI) membuat organisasi mengeluarkan investasi yang tidak bisa dibilang sedikit. Penelitian yang dilakukan Forrester Research, Inc. menunjukkan bahwa total investasi SI/TI secara global pada tahun 2010 bernilai USD 1,6 triliun [1]. Khusus pada industri rumah sakit, investasi SI/TI pada tahun 2011 diperkirakan akan menyentuh nilai USD 40 miliar [2]. Investasi yang besar tersebut membuktikan bahwa informasi merupakan sebuah aset penting yang mempunyai nilai ekonomis bagi perusahaan.

Keamanan aset informasi penting untuk diperhatikan seiring banyaknya serangan yang terjadi terhadap organisasi. Survey yang dilakukan FBI/CSI, $80 \%$ dari responden mengaku mengalami kerugian finansial yang disebabkan oleh terjadinya serangan, akan tetapi hanya $40 \%$ dari penderita serangan tersebut yang dapat menghitung berapa besar kerugian finansial yang dialami [3]. Hal tersebut dikarenakan perusahaan 
masih belum melakukan kuantifikasi nilai ekonomis terhadap aset informasi yang dimilikinya.

Industri rumah sakit merupakan salah satu organisasi yang memiliki aset informasi yang cukup banyak dan kompleks. Informasi yang terkandung di dalamnya seringkali bersifat rahasia dan tidak boleh diakses secara bebas. Kompleksitas bertambah ketika aset informasi tersebut tersebar di berbagai tempat dan tersimpan dalam bentuk fisik atau digital. Oleh sebab itu profilisasi terhadap aset informasi sangat perlu untuk dilakukan sebagai upaya awal dalam penerapan manajemen risiko keamanan informasi yang baik.

Profilisasi aset informasi adalah proses pemberian suatu identitas tersendiri pada setiap aset informasi. Salah satu cara profilisasi aset informasi dapat dilakukan dengan menggunakan Information Asset Profiling (IAP) [4]. Tujuan utama dari IAP adalah untuk memberikan definisi umum yang jelas pada setiap aset informasi. Kejelasan tersebut akan bermanfaat bagi setiap pemangku kepentingan yang ingin menuangkannya ke dalam bentuk penerapan strategi perlindungan dan perencanaan mitigasi risiko untuk aset tersebut. Keakuratan yang terdapat pada setiap identitas aset informasi akan berguna dalam pemilihan kontrol-kontrol perlindungan aset informasi.

\section{Metodologi}

Penelitian ini merupakan ringkasan dari Karya Akhir yang pernah ditulis [5] sehingga tabel hasil yang terdapat pada paper ini akan diringkas tanpa mengurangi isi dan kandungan. Penelitian dilakukan dengan menggunakan 4 tahapan. Pertama, penentuan ruang lingkup. Proses ini perlu untuk dilakukan mengingat kompleksnya aktivitas yang terdapat di dalam suatu industri rumah sakit. Penelitian ini akan membatasi ruang lingkup pada proses bisnis utama yang terjadi dalam pelayanan rumah sakit yang diberikan. Pemilihan proses bisnis utama diharapkan akan mewakili gambaran keseluruhan aktivitas utama yang terdapat pada industri rumah sakit. Kedua, profilisasi asset informasi. Aktivitas yang dilakukan pada tahapan ini disesuaikan dengan panduan proses IAP. Tujuannya adalah sebagai pembuktian bahwa pendekatan IAP dapat digunakan sebagai salah satu cara profilisasi aset informasi. Ketiga, analisis risiko asset informasi. Pada tahapan ini akan dilakukan analisis risiko terhadap aset informasi yang sudah teridentifikasi. Prosesnya adalah mencari sumber literatur tentang daftar risiko dari penelitian yang pernah dilakukan sebelumnya. Hasil yang didapatkan berupa jenis risiko yang mungkin terjadi terkait hilang atau rusaknya aset informasi. Keempat, kuantifikasi nilai ekonomis. Kuantifikasi dilakukan berdasarkan risiko yang teridentifikasi sebelumnya. Hasil akhirnya adalah berupa metriks perhitungan yang dapat digunakan untuk mencari nilai ekonomis dari suatu aset informasi.

\section{Hasil dan Pembahasan}

Dalam menentukan proses bisnis utama yang terdapat pada industri rumah sakit, perlu diketahui pelayanan apa saja yang terdapat di dalamnya. Pada dasarnya, pelayanan yang diberikan rumah sakit terdiri dari rawat inap, rawat jalan, dan instalasi gawat darurat [6]. Proses bisnis utama ditentukan dari kemiripan aktivitas yang terdapat dalam ketiga layanan tersebut sehingga membentuk suatu alur yang tergambar pada gambar 1 .

Alur proses bisnis utama pada industri rumah sakit dapat dikatakan mirip dengan proses pelayanan pada pasien rawat jalan. Proses dimulai ketika pasien datang ke rumah sakit untuk berobat. Pasien lalu mengambil nomor antrian untuk mendaftar. Setelah tiba gilirannnya, pasien menuju bagian pendaftaran yang akan diterima oleh resepsionis untuk melakukan registrasi. Bagi pasien lama atau yang sudah pernah berobat, mereka cukup untuk memberikan kartu pasien kepada resepsionis.

Apabila mereka lupa membawa kartu pasien, maka verifikasi dilakukan dengan memasukkan identitas pasien berupa nama, tanggal lahir serta alamat. Bagi pasien yang baru pertama kali datang untuk berobat, maka identitas dari pasien akan dimasukkan di dalam basis data rumah sakit, dan calon pasien tersebut akan mendapatkan kartu berobat untuk kemudian dapat digunakan kembali ketika datang ke rumah sakit.

Setelah proses registrasi selesai dilakukan, pasien akan mendapatkan nomor antrian untuk menunggu dilakukannya pemeriksaan. Petugas akan mempersiapkan data rekam medis dari pasien tersebut untuk kemudian diberikan kepada dokter yang akan menanganinya. Setelah tiba gilirannya, pasien menuju ruang pemeriksaan untuk diperiksa oleh dokter yang bertugas. Pada saat pemeriksaan telah selesai dilakukan, dokter kemudian akan memperbarui data rekam medis pasien dan membuatkan laporan tindakan medis yang telah dilakukan. Perawat akan mengambil laporan tersebut untuk diberikan ke bagian penagihan sementara pasien menuju bagian kasir untuk melakukan pembayaran.Pasien yang telah selesai melakukan pembayaran akan menuju ruang farmasi untuk memberikan daftar resep dan mendapatkan nomor urut pengambilan obat. 


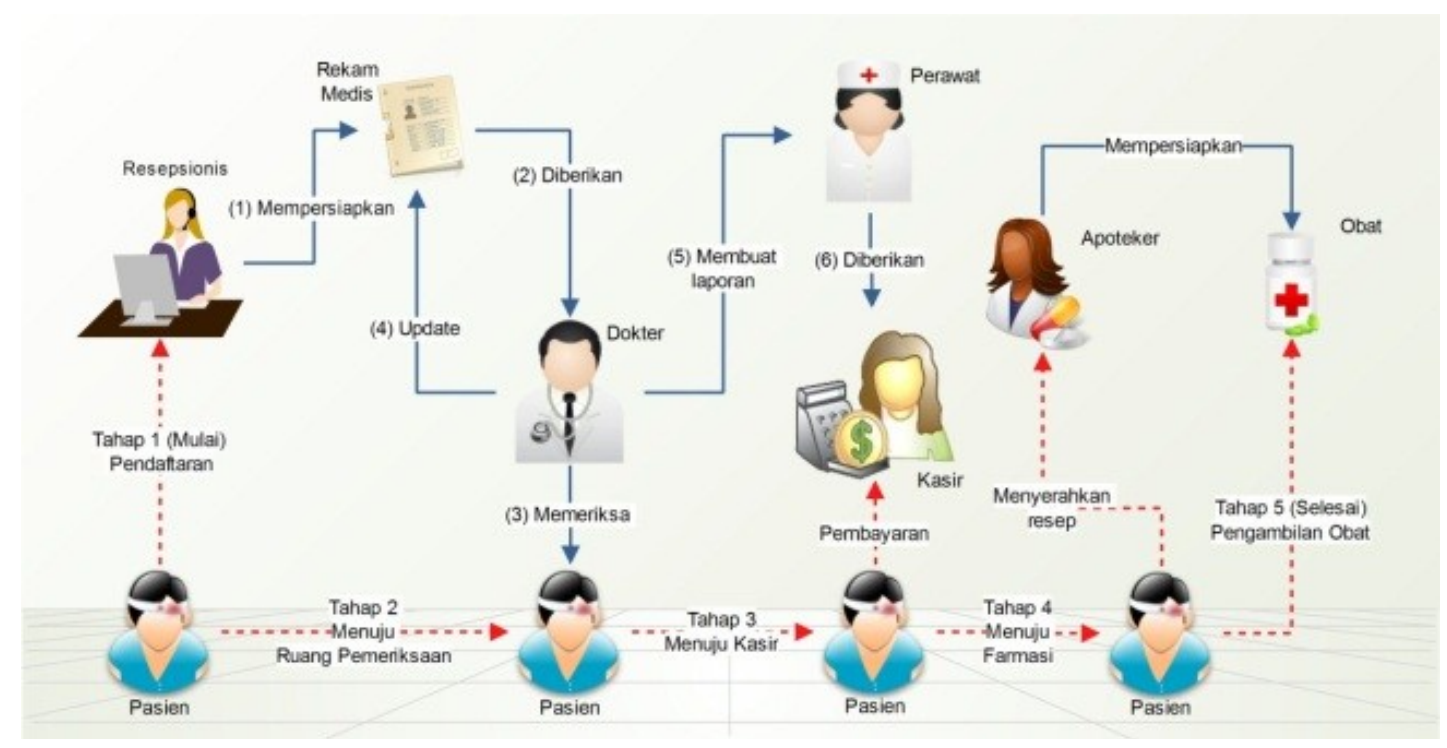

Gambar 1. Proses bisnis utama Rumah Sakit.

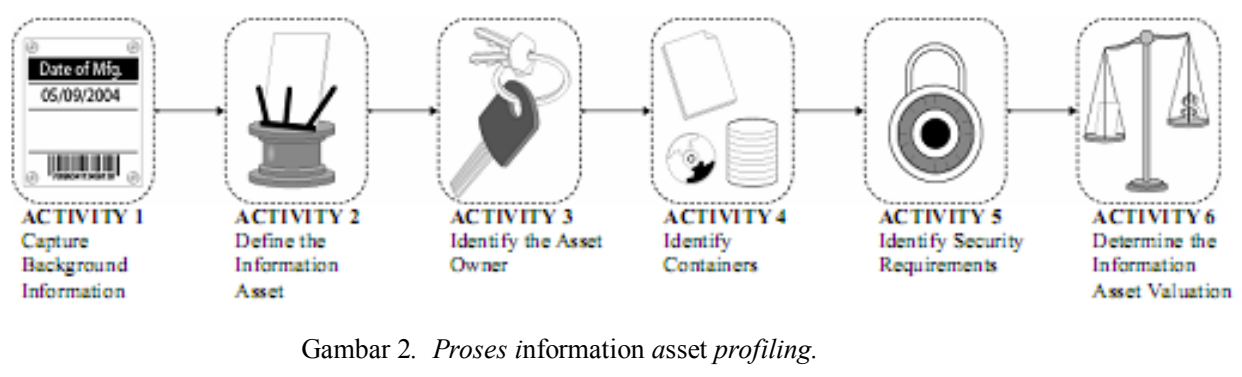

Apoteker kemudian mempersiapkan obat yang sesuai dengan daftar resep yang diterima. Setelah obat selesai dipersiapkan, pasien akan dipanggil sesuai nomor urutnya untuk selanjutnya dapat mengambil obatnya. Sampai disini proses pelayanan selesai untuk dilakukan.

Profilisasi aset informasi dilakukan dengan menggunakan aktivitas proses yang terdapat pada metodologi IAP yang tergambar pada gambar 2 .

Proses ini bertujuan untuk mengumpulkan informasi tentang siapa yang menyelesaikan profil dari aset informasi dan kapan profil tersebut akan diselesaikan. Seiring dengan berjalannya waktu maka aset informasi akan mengalami perubahan terhadap isi maupun kepemilikannya. Dengan tercatatnya latar belakang dari aset informasi maka akan berguna sebagai rekam jejak terhadap perkembangan aset informasi yang digunakan. Pencatatan dilakukan pada setiap aset informasi yang teridentifikasi dan berisi nama, identitas pembuat, tanggal pembuatan dan versi dari aset informasi. Contoh informasi latar belakang aset informasi dapat dilihat pada tabel I.
Aset informasi adalah sepotong informasi yang terdefinisi, disimpan dengan cara apapun, tidak mudah untuk diganti tanpa biaya, keahlian, waktu, sumber daya dan kombinasinya serta diakui sebagai sesuatu yang berharga bagi organisasi [7]. Identifikasi aset informasi yang dilakukan dalam penelitian berfokus pada ruang lingkup yang digunakan yaitu proses bisnis utamanya. Hasil identifikasinya dapat dilihat pada tabel II.

Dalam melakukan identifikasi pemilik aset dikenal dua peran yaitu pemilik (owner) dan kustodian (custodian). Pemilik adalah individu atau divisi yang memiliki tanggung jawab utama dalam kelangsungan dan ketahanan hidup dari suatu aset informasi. Sedangkan kustodian adalah individu atau divisi yang bertanggung jawab untuk melakukan proteksi terhadap aset informasi terkait penyimpanan, distribusi dan pemrosesan aset informasi.Peran pemilik adalah menentukan kebutuhan keamanan aset informasi dan bertanggung jawab dalam mengkomunikasikannya dengan seluruh kustodian. 
TABEL I

INFORMASI LATAR BELAKANG Profil Aset Informasi

\begin{tabular}{lll}
\multicolumn{3}{c}{ Profil Aset Informasi } \\
\hline $\begin{array}{l}\text { Nama Aset } \\
\text { Tanggal } \\
\text { dibuat }\end{array}$ & $\begin{array}{l}\text { Data rekam medis } \\
\text { 10 Jan 2011 }\end{array}$ & Versi \\
Pembuat & Mr. ABC, & MR XYZ, \\
& Sistem Analis, & $\begin{array}{l}\text { Dokter umum, } \\
\text { Anggota Komite }\end{array}$ \\
& $\begin{array}{l}\text { Divisi Teknologi } \\
\text { Informasi }\end{array}$ & \begin{tabular}{l} 
Medis \\
\hline
\end{tabular}
\end{tabular}

TABEL II

DAFTAR ASET INFORMASI

\begin{tabular}{clcl}
\hline No & \multicolumn{1}{c}{ Aset Informasi } & No & Aset Informasi \\
\hline 1 & Daftar IPAddress & 7 & Data resep \\
2 & Data karyawan & 8 & Data obat-obatan \\
3 & Jadwal karyawan & 9 & Stok obat-obatan \\
4 & Identitas pasien & 10 & Data keuangan \\
5 & Nomor urut antrian & 11 & Daftar inventori \\
6 & Data rekam medis & & \\
\hline
\end{tabular}

Pemilik juga bertanggung jawab dalam memberikan definisi dan ruang lingkup dari suatu aset informasi. Peran lain dari pemilik adalah pengertian mereka akan nilai dari aset informasi tersebut bagi organisasi baik dilihat dari segi finansial atau yang lainnya.

Peran kustodian adalah memastikan dan bertanggung jawab terhadap keamanan dari penampung aset informasi. Dalam arti lain, peran kustodian lebih ditekankan kepada sisi teknis dalam menentukan proteksi pengamanan aset informasi. Dengan kemampuan teknis tersebut, kustodian bertanggung jawab mengimplementasi kontrol pengamanan dari aset informasi pada tingkat penampung. Kustodian juga diharapkan dapat memberikan masukan kepada pemilik informasi dalam penerapan keamanan aset informasi. Pemilik atau kustodian dapat terdiri lebih dari satu pihak. Sebagai contoh suatu aset informasi yang disimpan dengan dua cara yaitu fisik dan digital, maka custodian-nya terdiri dari dua pihak yaitu pihak yang bertanggung jawab terhadap penyimpanan fisiknya dan pihak yang bertanggung jawab terhadap penyimpanan digitalnya. Contoh pemilik aset informasi dapat dilihat pada tabel III.

Identifikasi penampung aset dilakukan dengan cara membuat daftar dari semua penampung aset informasi. Dengan mengetahui secara jelas penampung dari aset informasi, maka jenis proteksi dan tingkatannya dapat ditentukan dan disesuaikan dengan karakteristik dari tiap-tiap penampung aset. Penampung dapat dikategorikan menjadi 4 tipe yaitu: (1)Aplikasi dan sistem, (2)Perangkat keras, (3)Manusia, dan (4)Penampung lainnya. Contoh identifikasi penampung aset dapat dilihat pada tabel IV.
TABEL III

PEMILIK ASET INFORMASI

\begin{tabular}{|c|c|c|c|}
\hline No & $\begin{array}{c}\text { Aset } \\
\text { Informasi }\end{array}$ & Pemilik & Kustodian \\
\hline 1 & $\begin{array}{l}\text { Data } \\
\text { karyawan }\end{array}$ & $\begin{array}{l}\text { Div. Sumber } \\
\text { Daya } \\
\text { Manusia }\end{array}$ & $\begin{array}{l}\text { Div. Teknologi } \\
\text { Informasi dan } \\
\text { Div. Sumber Daya } \\
\text { Manusia }\end{array}$ \\
\hline 2 & $\begin{array}{l}\text { Data rekam } \\
\text { medis }\end{array}$ & $\begin{array}{l}\text { Komite } \\
\text { Medis }\end{array}$ & $\begin{array}{l}\text { Div. Rekam } \\
\text { Medis }\end{array}$ \\
\hline 3 & $\begin{array}{l}\text { Data obat- } \\
\text { obatan }\end{array}$ & Div. Farmasi & $\begin{array}{l}\text { Div. Teknologi } \\
\text { Informasi }\end{array}$ \\
\hline 4 & $\begin{array}{l}\text { Stok obat- } \\
\text { obatan }\end{array}$ & Div. Farmasi & $\begin{array}{l}\text { Div. Teknologi } \\
\text { Informasi }\end{array}$ \\
\hline 5 & $\begin{array}{l}\text { Data } \\
\text { keuangan }\end{array}$ & $\begin{array}{l}\text { Div. } \\
\text { Keuangan }\end{array}$ & $\begin{array}{l}\text { Div. Teknologi } \\
\text { Informasi }\end{array}$ \\
\hline 6 & $\begin{array}{l}\text { Daftar } \\
\text { inventori }\end{array}$ & Div. Umum & $\begin{array}{l}\text { Div. Teknologi } \\
\text { Informasi }\end{array}$ \\
\hline
\end{tabular}

Identifikasi kebutuhan pengamanan aktivitas ini bertujuan untuk memberikan persyaratan yang spesifik terhadap ketiga aspek utama keamanan informasi yaitu aspek kerahasiaan (confidentiality), integritas (integrity), dan ketersediaan (availability) [8]. Setiap aspek akan diberikan tingkatan yang bernilai rendah, sedang atau tinggi [7] seperti terlihat pada tabel V. Dalam proses identifikasi kebutuhan pengamanan, kedetilan dan keakuratan akan identifikasi perlu diperhatikan.

TABEL IV

PENAMPUNG ASET INFORMASI

\begin{tabular}{ll}
\hline \multicolumn{2}{l}{ Aset Informasi : Data Keuangan } \\
\hline (1) Sistem dan Aplikasi & \\
Aplikasi & Oracle Finance \\
Sistem Operasi & Unix \\
Sistem \& Aplikasi lainnya & --- \\
\hline (2) Perangkat Keras & \\
Server \& Perangkat Keras & Server no. XXX \\
lainnya & LAN network \\
Jaringan \& segmen & \\
jaringan & PC no. XXX \\
$\begin{array}{l}\text { PC / perangkat keras } \\
\text { lainnya }\end{array}$ & \\
\hline $\begin{array}{l}\text { (3) Manusia } \\
\text { Unit Bisnis }\end{array}$ & Div. Keuangan \\
Personil Teknil & --- \\
Karyawan Lainnya & --- \\
\hline (4) Penampung Lainnya & \\
Lokasi Fisik Penyimpanan & Backup tapes \\
Kertas & $\begin{array}{l}\text { Dokumen fisik transaksi } \\
\text { (kuitansi, invoice, dll ) }\end{array}$ \\
$\begin{array}{l}\text { Penyimpanan personal dan } \\
\text { lokasi lainnya }\end{array}$ & ---- \\
\hline
\end{tabular}

Pengetahuan yang mendalam akan isi dari suatu aset informasi dan regulasi yang dapat digunakan sangat menentukan dari hasil proses identifikasi. 
TABEL V

TINGKATAN ASPEK UTAMA KEAMANAN INFORMASI

\begin{tabular}{|c|c|c|c|}
\hline \multirow[t]{2}{*}{ Tingkatan } & \multicolumn{3}{|c|}{ Aspek } \\
\hline & Kerahasiaan & Integritas & Ketersediaan \\
\hline Rendah & $\begin{array}{l}\text { Akses dari luar tidak menyebabkan } \\
\text { ancaman keamanan bagi organisasi }\end{array}$ & $\begin{array}{l}\text { Kurangnya integritas informasi } \\
\text { berdampak sangat minim bagi bisnis }\end{array}$ & $\begin{array}{l}\text { Toleransi tidak tersedianya } \\
\text { data sampai dengan } 7 \text { hari }\end{array}$ \\
\hline Sedang & $\begin{array}{l}\text { Bersifat cukup sensitif dan rahasia. } \\
\text { Akses tidak sah dapat menimbulkan } \\
\text { kerugian terbatas bagi organisasi }\end{array}$ & $\begin{array}{l}\text { Kurangnya integritas informasi } \\
\text { berdampak cukup signifikan bagi } \\
\text { bisnis }\end{array}$ & $\begin{array}{l}\text { Toleransi tidak tersedianya } \\
\text { data sampai dengan } 48 \text { jam }\end{array}$ \\
\hline Tinggi & $\begin{array}{l}\text { Bersifat sangat sensitif dan rahasia. } \\
\text { Akses tidak sah terhadap informasi } \\
\text { ini dapat menyebabkan kerugian yang } \\
\text { besar bagi organisasi. }\end{array}$ & $\begin{array}{l}\text { Akurasi dan kelengkapan data } \\
\text { merupakan sifat yang wajib dan tidak } \\
\text { dapat ditoleransi kekurangannya. }\end{array}$ & $\begin{array}{l}\text { Ketersediaan informasi } \\
\text { adalah } 24 \text { jam } x 7 \text { hari }\end{array}$ \\
\hline
\end{tabular}

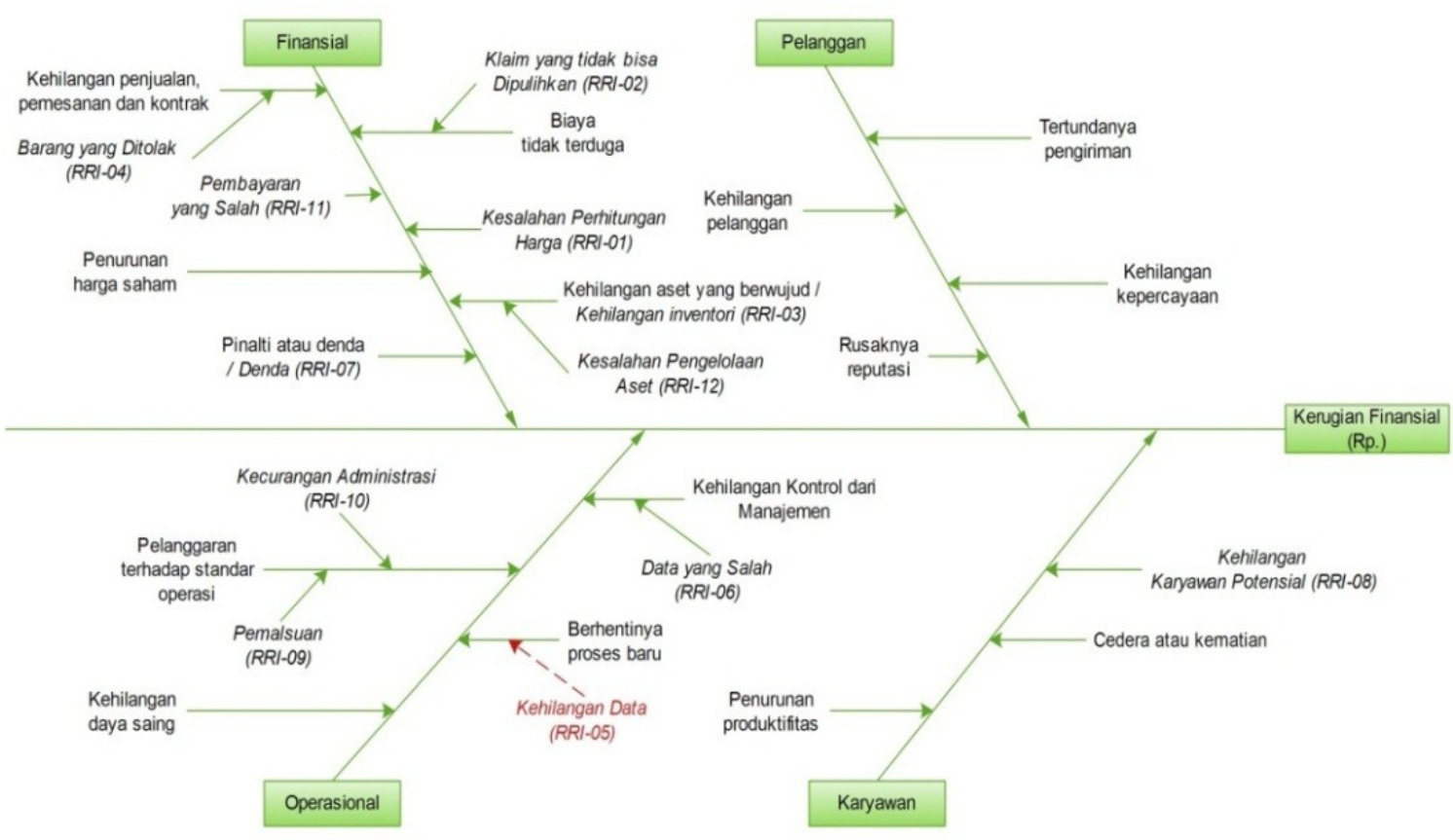

Gambar 3 Diagram resiko sebab akibat.

Penilaian aset informasi aktivitas ini bertujuan untuk mencari nilai berwujud ataupun tidak berwujud dari aset informasi. IAP tidak mempunyai formula khusus dalam mencari nilai aset informasi. Penelitian ini akan menggunakan teknik skoring untuk mencari nilai aset informasi [9].

Setiap aspek keamanan informasi akan diberikan skor pada tiap tingkatannya yaitu 1 untuk tingkatan rendah, 2 untuk tingkatan sedang, dan 3 untuk tingkatan tinggi. Kemudian dari skor tersebut akan dijumlah sehingga menghasilkan total skor yang merepresentasi-kan nilai aset informasi. Nilai aset informasi berguna untuk memberikan gambaran prioritasi dan tingkat pentingnya aset informasi bagi organisasi. Contoh hasil penilaian aset informasi dapat dilihat pada tabel VI.

Salah satu cara dalam melakukan kuantifikasi nilai ekonomis aset informasi adalah dengan menggunakan teknik analisis risiko [4] [10] [11]. Pendekatan ini melihat nilai ekonomis aset informasi dari kemungkinan risiko kerugian finansial yang timbul akibat hilangnya aset informasi. Penelitian ini menggunakan kategori risiko yang terdapat pada Tabel Manfaat Bisnis TI Generik Ranti [12] dan memetakannya ke dalam empat model dimensi dampak bisnis yaitu finansial, operasional, pelanggan dan karyawan [13]. Hasilnya ditunjukkan menggunakan diagram fishbone (lihat gambar 3) yang akan memudahkan proses identifikasi risiko dalam mencari nilai ekonomis aset informasi. Pada diagram fishbone, kategori risiko $\mathrm{Su}$ [13] dicetak menggunakan teks standar sementara risiko yang terdapat pada penelitian Ranti [12] dicetak miring dan dilengkapi kode di dalam tanda kurung. Khusus untuk kategori "Kehilangan Data (RRI-05)" dicetak dengan menggunakan warna yang berbeda dan garis panahnya dibuat putus-putus. Hal ini dibuat dengan tujuan bahwa kategori tersebut sebenarnya dapat diposisikan dimana saja dan dapat merupakan penyebab dari risiko lainnya. Sebagai asumsi, risiko "Kehilangan Data (RRI- 
05)" ditempatkan sebagai penyebab dari risiko "Berhentinya proses baru" dan merupakan dampak "Operasional", yang pada akhirnya dapat mengakibatkan kerugian finansial.

Pada penelitian ini, kuantifikasi nilai ekonomis aset informasi didasari pada analisis risiko terhadap kerugian finansial yang mungkin terjadi apabila aset informasi hilang. Atas dasar tersebut maka perlu untuk dilakukan penentuan tingkatan pemulihan data (recoverability) pada aset informasi [5] yang dapat dilihat pada tabel VII.

Dalam memilih aset informasi mana yang akan dihitung nilai ekonomisnya, maka digunakan pertimbangan yang ditinjau dari nilai aset dan tingkat pemulihan data. Aset informasi yang akan dipilih sebaiknya mempunyai nilai aset $\geq 6$ dan memiliki tingkat pemulihan data sedang atau sulit.

Nilai aset $\geq 6$ merupakan nilai minimal yang didapatkan apabila setiap aspek keamanan informasi bernilai sedang sehingga aset tersebut dianggap cukup penting bagi organisasi. Sedangkan tingkat pemulihan data yang sedang atau sulit menunjukkan bahwa apabila suatu aset informasi hilang maka akan dapat menimbulkan kerugian yang signifikan bagi organisasi baik secara operasional maupun finansial.

TABEL VI

NILAI ASET INFORMASI

\begin{tabular}{lccc}
\multicolumn{4}{c}{ NILAI ASET INFORMASI } \\
\hline \multicolumn{4}{c}{ Aset Informasi : Data Keuangan } \\
\hline Aspek & Kerahasiaan & Integritas & Ketersediaan \\
Tingkatan & Tinggi & Tinggi & Tinggi \\
Skor & 3 & 3 & 3 \\
\hline Total Skor / Nilai Aset Informasi & 9 \\
\hline
\end{tabular}

TABEL VII

TINGKATAN PEMULIHAN DATA

\begin{tabular}{|c|c|}
\hline Tingkatan & Keterangan \\
\hline Mudah & $\begin{array}{l}\text { Pemulihan data dapat dilakukan dengan } \\
\text { mudah, artinya sumber datanya tersedia serta } \\
\text { mudah untuk didapatkan. Pemulihan data } \\
\text { juga tidak memakan waktu vang lama. }\end{array}$ \\
\hline Sedang & $\begin{array}{l}\text { Pemulihan data dapat dilakukan dengan } \\
\text { mudah, artinya sumber datanya tersedia serta } \\
\text { mudah untuk didapatkan. Akan tetapi dalam } \\
\text { melakukan pemulihan data dibutuhkan } \\
\text { waktu yang relatif cukup lama. }\end{array}$ \\
\hline Sulit & $\begin{array}{l}\text { Pemulihan data sulit untuk dilakukan } \\
\text { dikarenakan sumber datanya tidak tersedia } \\
\text { atau sulit untuk diadakan. Hal tersebut akan } \\
\text { menyebabkan waktu yang digunakan dalam } \\
\text { pemulihan data menjadi sangat lama. }\end{array}$ \\
\hline
\end{tabular}

Kuantifikasi dilakukan berdasarkan asumsi keadaan yang dapat diterima pada suatu organisasi. Asumsi keadaan dapat diperoleh dengan melihat diagram dari analisis risiko yang telah dilakukan. Dari asumsi tersebut maka akan dapat ditentukan metrik perhitungan nilai ekonomis. Metrik perhitungan tersebut berguna dalam mencari nilai ekonomis suatu aset informasi terkait kerugian finansial yang mungkin terjadi akibat hilangnya aset informasi. Contoh metrik perhitungan nilai ekonomis aset informasi dapat dilihat pada tabel VIII.

TABEL VIII

METRIK NILAI EKONOMIS ASET INFORMASI

\begin{tabular}{lll}
\hline Aset Informasi : & Data Keuangan & \\
\hline Analisis & Kehilangan Data $\rightarrow$ & Kesalahan \\
Risiko & Perhitungan Harga $\rightarrow$ Kerugian \\
Asumsi & Finansial & \\
& Hilangnya dokumen transaksi akan \\
& mengakibatkan kesalahan perhitungan \\
& harga. Kesalahan tersebut akan \\
& menimbulkan selisih dari biaya yang \\
& seharusnya diperoleh. & \\
& Hal tersebut tentunya akan \\
& menimbulkan kerugian finansial bagi \\
Metrik & perusahaan. \\
Perhitungan & Rata-rata pendapatan per tahun \\
& - & \\
& (persentase probabilitas kesalahan \\
& hitung \\
& $\times$ Rata-rata pendapatan per tahun) \\
\hline
\end{tabular}

\section{Kesimpulan}

IAP terbukti dapat digunakan sebagai metode dalam pengelolaan aset informasi. Profilisasi yang dilakukan didalamnya dianggap sebagai suatu best practice dalam penerapan awal manajemen risiko. Dengan terprofilkan-nya aset informasi, maka penerapan keamanan informasi akan dapat dikembangkan dengan lebih baik.

Pada penelitian ini diketahui bahwa nilai aset informasi tidak selalu berbanding lurus dengan nilai ekonomisnya. Hal tersebut dikarenakan nilai aset hanya menunjukkan seberapa pentingnya aset tersebut bagi perusahaan. Akan tetapi apabila aset tersebut hilang dan ternyata mudah untuk dipulihkan maka nilai ekonomisnya dianggap tidak terlalu tinggi karena kerugian finansial yang terjadi tidak besar. Oleh karena itu dalam membantu menghitung nilai ekonomis aset informasi maka perlu untuk ditentukan tingkat pemulihan datanya terlebih dahulu.

Nilai ekonomis aset informasi tergolong sulit untuk dihitung karena dianggap sebagai sesuatu yang intangible. Sebagai bentuk pendekatan dalam mencari sesuatu yang dianggap intangible tersebut, maka digunakan diagram analisis risiko kerugian finansial. Fishbone diagram yang dihasilkan diharapkan dapat menggambarkan suatu pemetaan hubungan sebab akibat yang berujung pada sesuatu yang tangible yaitu kerugian finansial.

Rekomendasi yang dapat diberikan untuk penelitian selanjutnya terdiri dari beberapa poin. Pertama, kuantifikasi nilai ekonomis aset informasi hendaknya dapat diukur dari hilangnya integritas data. Pemalsuan, data yang salah, data yang berubah serta data yang diakses oleh pihak 
yang tidak berwenang merupakan salah satu ciri hilangnya integritas dari data tersebut. Hal ini sangat penting karena hilangnya integritas ini merupakan salah satu risiko yang akan menyebabkan kerugian finansial yang tidak sedikit bagi organisasi. Kedua, nilai suatu informasi dapat berubah sesuai dengan kegunaan dan pemanfaatannya dalam organisasi. Untuk itu hendaknya dapat dilakukan evaluasi nilai ekonomis aset informasi dalam satu kurun waktu tertentu. Hal tersebut dapat menjadi dasar yang kuat apabila pengadaan awal suatu aset informasi membutuhkan biaya yang cukup besar Kuantifikasi dapat dilakukan dengan membandingkan biaya awal yang dikeluarkan dalam mendapatkan informasi (historical cost) dengan nilai aset informasi pada saat ini (current value). Ketiga, tahapan yang terdapat pada IAP dapat dimodifikasi kembali, sebagai contoh pada aktivitas terakhir yaitu "Menentukan penilaian aset informasi" dilakukan terlebih dahulu sebelum melakukan aktivitas "Mengidentifikasi kebutuhan-kebutuhan pengamanan". Hal tersebut bertujuan untuk justifikasi biaya yang akan dikeluarkan dalam rangka pemenuhan kebutuhan pengamanan apakah sebanding atau tidak dengan nilai ekonomis aset informasi yang akan dilindungi.

\section{Referensi}

[1] Forrester Research, IT Spending to Rebound In 2010, http://www.forrester.com/ER/Press/Release/ 0,1769,1317,00.html, 2010, retrieved January 24, 2011.

[2] L. Meirian, Computer World, http://www.computerworld.com/s/article/ 9217065/Healthcare_IT_spending_to_hit_40 B_this_year, 2011, retrieved June 10, 2011.

[3] D. Tan, Quantitative Risk Analysis Step-byStep, GSEC Practical Version 1.4b - Option
12002.

[4] J.F. Stevens, Information Asset Profiling, Technical Note CMU/SEI-2005-TN-021 2005.

[5] M.T. Wicaksono, "Kajian Profilisasi Dan Kuantifikasi Aset Informasi Menggunakan Information Asset Profiling dalam Penerapan Sistem Manajemen Keamanan Informasi (SMKI) ISO 27001 pada Industri Rumah Sakit: Studi Kasus Rumah Sakit Pondok Indah,"Ph.D Thesis, Magister of Information Technology, Faculty of Computer Science, University Indonesia, Indonesia, 2011.

[6] Undang-Undang Republik Indonesia Nomor 44 Tahun 2009 tentang Rumah Sakit, 2009.

[7] Guideline for Information Asset Valuation, ISO27k Implementer's Forum, 2009.

[8] J. Kouns \& D. Minoli, Information Technology Risk Management in Enterprise Environment, John Wiley \& Sons, Inc, New Jersey, 2010.

[9] Matrices for Asset Valuation and Risk Analysis, ISO27k Implementer's Forum, 2009.

[10] C. Oppenheim, R.M.S. Wilson, \&J. Stenson, "Valuation of Information Asset,"Research Series Paper, vol. 2, pp. 1-38, 2000.

[11] R.S. Poore, "Valuing Information Assets for Security Risk Management,"Information System Security, vol. 9, pp. 1-7, 2000.

[12] B. Ranti, "Identification of Information Systems / Information Technology Business Values with Hermeneutic Approach: Cases in Indonesia," Ph.D Thesis, Faculty of Computer Science, University Indonesia, 2008.

[13] X. Su, An Overview of Economic Approaches to Information Security Management, Technical Report TR-CTIT06-30 TR-CTIT-06-30, 2006. 